\title{
Statistics on the Implementation of Exclusionary Rules in China
}

\author{
Jiang $\mathrm{Na}^{1} \&$ Han Rong ${ }^{2}$ \\ ${ }^{1}$ Professor, College for Criminal Law Science, Beijing Normal University (BNU), P. R. China \\ ${ }^{2}$ L.L.M. Candidate, Law School of BNU \\ Correspondence: Professor Jiang Na, College for Criminal Law Science, BNU, Beijing (100875), P. R. China. E-mail: \\ na.jiang@bnu.edu.cn;
}

Received: November 16, 2018

Accepted: December 11, 2018 Online Published: December 13, 2018

doi:10.11114/ijlpa.v1i2.3880

URL: https://doi.org/10.11114/ijlpa.v1i2.3880

\begin{abstract}
The media report that the rate of the actual implementation of exclusionary rules is very low in China, even lower than many of other countries in the world. This paper will start from Chinese academic findings on their current implementation. Further, it will proceed with Chinese official data on the actual implementation of exclusionary rules. Then, it will conclude with the common problems of such statistics that need to be mended in future reforms, in order to ensure better justice in China.
\end{abstract}

Keywords: Statistics, Implementation, Exclusionary Rules, China

\section{Introduction}

The media often report that the rate of the actual implementation of exclusionary rules is very low in any countries of the world. It happens not only in European countries and North American countries, but also in all jurisdictions of China. After a series of justice reforms have been taken for the past decade in Mainland China, the public frequently challenges the current implementation of exclusionary rules. Both Chinese academic research and official data are main sources of their implementation, albeit with diverse ideas and common points from different perspectives. The both can reveal some of major problems on the use of such rules in China's justice practice.

Based on the 2010 Evidence Rules, the PRC adopted the 2012 Criminal Procedure Law (CPL) as a basic law, suggesting valuable rules to exclude illegally obtained evidence. The $2012 C P L$ has significantly expanded its formal requirements for the rules. These provisions can be mainly found in the $2012 \mathrm{CPL}, 2010$ Evidence Rules, the SPC's explanations, the MPS' Working Rules and 2017 Regulation on Some Issues of Strictly Excluding Illegally Obtained Evidence in Handling Criminal Cases. The 2012 CPL prohibits such evidence by many means. For instance, Article 50 of the 2012 CPL explicitly bars extorting confessions by torture or gathering evidence by threat, enticement, deceit or other illegal means.

There are many public debates on exclusionary rules in China. For example, some critics hold that while coerced oral statements cannot be used at trials, physical and documentary evidence derived from such statements can be used as evidence. ${ }^{1}$ This paper will start from Chinese academic findings on their current implementation. Further, it will proceed with Chinese official data on the actual implementation of exclusionary rules. Then, it will conclude with the common problems of such statistics that need to be mended in future criminal justice reforms, in order to ensure better justice in contemporary China.

\section{Chinese Academic Findings on the Current Implementation}

There are limited statistics on the implementation of exclusionary rules available in Mainland China. They include

\footnotetext{
${ }^{1}$ See CHEN Ruchao, "The Chinese Rectification of Inquisition by Torture”, Gansu ZhengzhiXueyuanXuebao, 2015-1, 1; “The Focus of 'First Case of Excluding Illegal Evidence in China': Whether Fatigue in Investigation is Torture or not", China Youth (3 September 2011), available online at http://news.xinhuanet.com/legal/2011-09/03/c_121958850.htm; Na Jiang, "Problems and Prospects: China's Response to Wrongful Convictions”, International Journal of Law, Crime and Justice, 2015/1
} 
official data on new progress in implementation of exclusionary rules and academic findings on problems in the actual implementation.

Among of the both, academic research based on data cannot show significant progress after evidence reforms. For instance, the Criminal Procedure Law Institution of China University of Political Science and Law developed a pilot project on exclusionary rules in 2009 at three Basic Peoples' Courts (BPCs) out of nine BPCs in Yancheng City of Jiangsu Province. The three ones received 34 cases involving the application for illegally obtained evidence for a period of six months, from May 28 to November 28, 2010. The rate of applications was $5.2 \%$ in the three, higher than $0.6 \%$ as the rate in other six BPCs located in the same City during the same period of time. Also, the rate of cases with lawyers involved was $47.8 \%$ in the three pilots during the above period, higher than $33.9 \%$ as the rate in other six BPCs during the same period, and $30.7 \%$ as the rate in the three pilots during six months before the pilot period. ${ }^{2}$ With more lawyers to help apply for excluding the evidence, defendants' expectation from lawyers was increasing, but their initiative application was reported to be rare. ${ }^{3}$

Another example is an academic survey on the actual implementation of the 2010 Evidence Regulations among judges responsible for criminal trials in a court located in Guangzhou City of Guangdong Province. ${ }^{4}$ In about $25 \%$ of cases that interviewed judges here, the defence argued that pre-trial confessions were illegally obtained before the implementation, whereas after that the defence did so in about $30 \%$ of the cases. Although the defence can provide clues or evidence sources in $55 \%$ of the $30 \%$ part, courts only identify $5 \%$ of the $55 \%$ as cases involving illegally obtained evidence.

Also, the cases involving torture was found to be about $10 \%$ of all cases in the survey and only $1 \%$ of those involving torture had been officially identified as those with tortured confession. About $10 \%$ of the cases were found to include technical flaws, of which $85 \%$ can be used as the basis of deciding cases after "corrections or reasonable explanations". Although about $5 \%$ of interrogation transcripts were not checked, confirmed, signed or fingerprinted by suspects, almost all or exactly about $90 \%$ of the flawed were still used for deciding cases. In the surveyed cases, about $50 \%$ of material or documentary evidence was from suspects' confession or identification. Among the half, about $5 \%$ of it involves tortured confession and another $10 \%$ or so involves threats, enticement and deceit. Even so, about $80 \%$ of the flawed half was still used as the basis of deciding cases. Among the material or documentary evidence that the police provided to the court, approximately $15 \%$ involves technical flaws, of which about $80 \%$ have been "corrected or reasonably explained" for being used as the bases of deciding cases. Before the implementation, in cases involving requests of proving the course of collecting evidence to be legal, about $85 \%$ of all cases involve the approach of official seals in explanatory materials, whereas $80 \%$ of the cases after the implementation. ${ }^{5}$ There is no significant change on the new reforms in practice.

Furthermore, some scholars investigated the implementation of the new law from 10 December 2012 to 9 December 2013 in the Higher People's Court (HPC), an Intermediate People's Court (IPC) and two BPCs of S Province. After interviewing 52 judges, handing out 80 copies of questionnaires and collecting 51 valid questionnaires, no case was found to exclude illegally obtained evidence with courts to initiatively start the application procedure for excluding the evidence. $^{6}$ Also in the same survey, only 104 cases involved the application for excluding it among 3,832 cases in total, accounting for $2.7 \%$. In a strict sense, the low rate of cases involving such application cannot necessarily suggest the poor implementation of the $2012 C P L .^{7}$ Even among the limited cases, such courts only investigated the legality of the collected evidence in $48.1 \%$ of the cases involving the applications. ${ }^{8}$

\section{Chinese Official Data on the Actual Implementation of Exclusionary Rules}

Differently, official data pay more attention to achievements than to shortfalls. According to statistics as of the end of 2011, the Ministry of Public Security (MOPS) finished transforming 70\% of all working places in the public security

${ }^{2}$ GUO Xinyang, 2012.

${ }^{3}$ GUO Xinyang, 2012.

${ }^{4}$ HE Jiahong, 2013.

${ }^{5}$ Art. 7(3) of Exclusionary Rules states that explanation documents provided by prosecutors with stamps on, cannot be admitted as evidence to prove the legitimacy of collecting evidence, unless the relevant investigators signed their names on or annexed their seals to the documents.

${ }^{6}$ See ZUO Weimin, 2015 at 152.

${ }^{7}$ GUO Xinyang, 2012.

${ }^{8}$ GUO Xinyang, 2012. 
organs. ${ }^{9}$ According to the MOPS' statistics, Chinese cases of tortured confession occurred in 2012 decreased to $87 \%$ of the average number of such cases in the past years. ${ }^{10}$ Until June 2013, the transformation of functional areas has been done in $90 \%$ of all police stations in order to implement the audio and video recording of interrogating suspects in the entire course of interrogations. ${ }^{11}$ Such efforts are important to safeguard the legitimacy of police interrogation. In 2013 and 2014, procuratorial organs are reported to exclude the use of illegally obtained evidence in 1,285 cases before deciding to arrest or prosecute suspects, corrected 3,797 investigators' illegal means by which to collect evidence, and also requested 16,000 persons to make corrections on such evidence. ${ }^{12}$

Another empirical study of the early implementation of the new $C P L$ also showed problems in implementation. ${ }^{13} \mathrm{~A}$ survey of recording practices by prosecutors in Fujian Province from January to October 2013 has shown some prosecutors or leaders cannot fully recognise the important role of synchronised recording in preventing torture and excluding tortured confession. ${ }^{14}$ Also, local people's Procuratorates' investment in recording technology was far from insufficient to meet the actual needs of providing dedicated interrogation rooms and other recording equipments. ${ }^{15}$ This survey found that among the 96 Procuratorial agencies in the same province, two thirds (67\%) only had one employee to record interrogations, and $61 \%$ of such agencies merely have part-time employees to do so. The serious lack of recording employees reveals the fact that interrogators often or at least sometimes conduct recordings. Clearly, this practice fails to separate sections in conducting recording from those in interrogating suspects during investigation, detrimental to justice. ${ }^{16}$

In fact, prosecutors showed no interest in recording requirements or concern about allegations of torture in interrogations before or after the implementation of the 2012 CPL. Another survey was conducted among 642 participants as prosecutors, judges, police officers or lawyers of a Chinese province, in order to examine their attitudes towards torture during investigation. ${ }^{17}$ The finding is that $79.7 \%$ of lawyers reported that prosecutors had no response to the allegation of torture in interrogations, and that $45.7 \%$ of the prosecutors agreed that they would not address the allegation. ${ }^{18}$

\section{Conclusion}

As main sources of examining the actual implementation of exclusionary rules, Chinese academic research and official data present their findings or comments on the implementation. Their focuses differ, but the implementation rate still remains low. Although the use of such rules has been widespread in China, behind new progress a series of problems remain, detrimental to justice as usual. Hence, further reforms are needed to improve both the rate and effect of their implementation in China's practice.

By domestic legislation, there is no way to exclude all of tortured confessions without a definition on torture. It is necessary for the PRC to define it in a much broader sense than its current scope in future reforms. ${ }^{19}$ At the very least, anyone acting in a public capacity should be responsible for the crimes of torture in the $1997 \mathrm{CL}$, albeit with several crimes like the crimes of extracting confession or testimony by force and of torturing detainees included. Also, both

${ }^{9}$ SU Haiping, The Standardization of Law Enforcement by Police Pans out; 70\% of the Case Processing Locationshave Improved (gong'an zhifa guifan hua qude chengxiao), (CHINANEWS, 14 November 2011), available online at <http://www.chinanews.com/fz/2011/11-14/3458312.shtml>, accessed 26 March 2017.

${ }^{10}$ See SONG Shijing, The Cases of Inquisition by Torture decreased by $81 \%$ in the Last Year, available online at <http://epaper.bjnews.com.cn/html/2013-06/27/content_443457.htm?div=-1>, (The Beijing News, 27 June 2013)

${ }^{11}$ See GUO Xinyang, 2012.

${ }^{12}$ See SUN Qian, Several Speculations on the Enforcement of the Modified Criminal Procedure Law, JianchaRibao, 09 April 2015), available online at <http://newspaper.jcrb.com/html/2015-04/09/content_183681.htm>

${ }^{13}$ LI Mingrong//TENG Zhong/Zhang Min, 2014 at 40.

${ }^{14}$ LI Mingrong//TENG Zhong/Zhang Min, 2014 at 40

${ }^{15}$ LI Mingrong//TENG Zhong/Zhang Min, 2014 at 40.

${ }^{16}$ LI Mingrong//TENG Zhong/Zhang Min, 2014 at 41.

${ }^{17}$ LIANG Bin /HENi Phil /LU Hong, 2014 at 591.

${ }^{18}$ LIANG Bin /HENi Phil /LU Hong, 2014 at 594.

${ }^{19}$ See YANG Yuguan, On the rule of excluding illegal evidence under the rule of law, Zhengju Kexue, 2015-4, 389; CHEN Ruihua, On the Rules about the Confession of the Accused, Faxue Zazhi, 2012-6. 46; DU Yusu, The Dilemma of the Trial Process about the Exclusionary Rule and its Improvement, Falv Kexue, 2013-6, 184. 
public officials and private citizens who commit acts of torture should equally become offenders of such crimes in PRC law.

Also, it is worthy of note that some articles conflict with the prohibition of torture and even tolerate some forms of torture in a sense. For example, Article 118 of the 2012 CPL requires criminal suspects to truthfully answer investigators' questions, which excludes the right to silence or privilege against self-incrimination and suggests that investigators may pressure suspects to confess. But mental or physical torture cannot be permitted. In order to prevent and exclude all forms of illegally obtained evidence, China needs to enshrine the accused a legal right to silence in the criminal process in future.

\section{Reference}

GUO, Xinyang. (2012). The Exclusionary Rule in Light of Procuratorial Reform, Guojia Jianchaguan Xueyuan Xuebao, $5,9-16$.

HE, Jiahong. (2013). Judicial Precedents are Needed in the Application of Exclusionary Rule, Faxue Jia, 2, 106-118.

LI, Mingrong, TENG, Zhong, Zhang, Min. (2014). Research Report on the Procuratorates' Implementation of the Criminal Procedure Law in Fujian Province, Guojia Jianchaguan Xueyuan Xuebao, 5, 40-54.

LIANG, Bin, HE, Ni Phil, LU, Hong. (2014). The Deep Divide in China's Criminal Justice System: Contrasting Perceptions of Lawyers and the Iron Triangle. Crime, Law and Social Change, 62, 585-601.

SONG, Shijing. (27 June 2013). The Cases of Inquisition by Torture decreased by $81 \%$ in the Last Year, The Beijing News, Retrieved from http://epaper.bjnews.com.cn/html/2013-06/27/content_443457.htm?div=-1

SU, Haiping. (14 November 2011). The Standardization of Law Enforcement by Police Pans out; chinanews, Retrieved from http://www.chinanews.com/fz/2011/11-14/3458312.shtml

SUN, Qian. Several Speculations on the Enforcement of the Modified Criminal Procedure Law, Jiancha Ribao (09 April 2015), Retrieved from http://newspaper.jcrb.com/html/2015-04/09/content_183681.htm

ZUO, Weimin (2015). The Favourite and the Underdog in the Empirical Research on the Exclusionary Rule, FashangYanjiu, 3, 151-160

\section{Copyrights}

Copyright for this article is retained by the author(s), with first publication rights granted to the journal.

This is an open-access article distributed under the terms and conditions of the Creative Commons Attribution License which permits unrestricted use, distribution, and reproduction in any medium, provided the original work is properly cited. 